\title{
Correction to: Acute aquatic toxicity of tire and road wear particles to alga, daphnid, and fish
}

\author{
Christopher Marwood ${ }^{1,5} \cdot$ Britt McAtee $^{2} \cdot$ Marisa Kreider $^{2} \cdot$ R. Scott Ogle ${ }^{3} \cdot$ Brent Finley $^{4} \cdot$ Len Sweet $^{2,6} \cdot$ Julie Panko $^{2}$
}

Published online: 19 May 2020

(c) The Author(s) 2020

Correction to: Ecotoxicology (2011) 20:2079-2089

https://doi.org/10.1007/s10646-011-0750-x

The article Acute aquatic toxicity of tire and road wear particles to alga, daphnid, and fish, written by Christopher Marwood, Britt McAtee, Marisa Kreider, R. Scott Ogle, Brent Finley, Len Sweet, and Julie Panko, was originally published electronically on the publisher's internet portal on 26 July 2011 without open access. With the author(s)' decision to opt for Open Choice the copyright of the article changed on May 2020 to (c) The Author(s) 2020 and the article is forthwith distributed under a Creative Commons Attribution 4.0 International License (https://creativecommons.org/licenses/by/4.0/), which permits use, sharing, adaptation, distribution and reproduction in any medium or format, as long as you give appropriate credit to the original author(s) and the source, provide a link to the Creative Commons licence, and indicate if changes were made.

The original article can be found online at https://doi.org/10.1007/ s10646-011-0750-x.

Julie Panko

jpanko@chemrisk.com

1 ChemRisk Canada, 291 Woodlawn Road West, Guelph, ON N1H 7L6, Canada

2 ChemRisk, 20 Stanwix Street, Suite 505, Pittsburgh, PA 15222, USA

3 Pacific EcoRisk, Inc., 2250 Cordelia Road, Fairfield, CA 94534, USA

4 ChemRisk, 25 Jessie Street, Suite 1800, San Francisco, CA 94105 , USA

5 Present address: NovaTox Inc., 10 Crane Avenue, Guelph, ON N1G 2R2, Canada

6 Present address: School of Public Health, University of Michigan, 1415 Washington Heights, Ann Arbor, MI 48109, USA

Publisher's Note Springer Nature remains neutral with regard to jurisdictional claims in published maps and institutional affiliations.

Open Access This article is licensed under a Creative Commons Attribution 4.0 International License, which permits use, sharing, adaptation, distribution and reproduction in any medium or format, as long as you give appropriate credit to the original author(s) and the source, provide a link to the Creative Commons license, and indicate if changes were made. The images or other third party material in this article are included in the article's Creative Commons license, unless indicated otherwise in a credit line to the material. If material is not included in the article's Creative Commons license and your intended use is not permitted by statutory regulation or exceeds the permitted use, you will need to obtain permission directly from the copyright holder. To view a copy of this license, visit http://creativecommons. org/licenses/by/4.0/. 